\title{
RANCANG BANGUN APLIKASI SISTEM DIAGNOSIS KERUSAKAN PADA MOBIL DAIHATSU XENIA 1.3 M/T DENGAN METODE FORWARD CHAINING
}

\author{
Ri Sabti Septarini ${ }^{1}$, Thesar Nugroho ${ }^{2}$ \\ Program Studi Informatika \\ Fakultas Teknik Universitas Muhammadiyah Tangerang \\ Jl. Perintis Kemerdekaan 1/33 Cikokol Kota Tangerang \\ Risabtis@ft-umt.ac.id \\ Thesar.veteran76@gmail.com
}

\begin{abstract}
Cars have properties like humans. The car will show certain signs before it breaks. Corrective action is taken when the symptoms occur.The problem faced is that many car Users who do not know it or may know only a little and not everyone knows about it in repairing the car.The purpose of writing this thesis report is to help detect damage to Daihatsu Xenia $1.3 \mathrm{M} / \mathrm{T}$ cars as an alternative solution for vehicle Users in shortening decision making time.Research methods conducted by the author in conducting research at PT. ArmadaAuto Tara. Fleet includes direct observation of the current diagnostic system, interviews with the head of mechanics and mechanics and literature studies that are relevant to the problems faced by the author. This study uses the Forward Chaining method.The results of this study can be seen that with the application of an expert diagnostic system this car damage can help the User get information about the damage experienced in his car without having to come to the workshop or to the expert.
\end{abstract}

Keywords: application, diagnosis, Forward Chaining, daihatsu, expert.

\section{PENDAHULUAN}

Mobil mempunyai sifat seperti manusia. Mobil akan menunjukkan tanda-tanda tertentu sebelum rusak. Tanda-tanda kerusakan yang muncul dapat dikenali dengan mudah jika kita terlatih, karena pada umumnya gejala-gejala tersebut dapat dirasakan oleh panca indera.

Masalahnya banyak pemakai mobil yang tidak mengetahuinya atau mungkin tahu hanya sedikit serta tidak semua orang mengetahuinya dalam perbaikan mobil tersebut. Cara yang paling mudah ialah dengan cara bertanya kepada bengkel, ahli reparasi itulah yang akan memeriksa atau mendiagnosa, mengatasi serta memperbaiki yang terjadi pada gangguangangguan tersebut.

Keberadaan seorang ahli sangat dibutuhkan oleh banyak orang tetapi dalam hal ini keberadaan seorang ahli sangat dipengaruhi oleh keadaan emosi dan kesehatan, motivasi dan lain- lain. Pada kondisi tertentu seseorang berkonsentrasi pada pekerjaannya bahkan sangat disayangkan bila seorang ahli itu meninggal dunia, sehingga keahlian orang tersebut akan terkubur tanpa bisa dimanfaatkannya.

Oleh sebab itu, maksud dan tujuan penulis dalam penelitian ini untuk merancang bangung aplikasi sistem pakar diagnosa kerusakan mobil Daihatsu Xenia 1.3 M/T sebagai alternatif solusi bagi pengguna kendaraan dalam mempersingkat waktu pengambilan keputusan dan membantu pengguna Daihatsu Xenia 1.3 M/T untuk lebih mengenal gejala-gejala kerusakan pada kendaraannya.
II. TINJAUAN PUSTAKA
A. Perancangan
Menurut Muslihudin Perancangan Sistem adalah sebuah teknik pemecahan masalah yang saling melengkapi (dengan analisis sistem) yang 
mengangkat kembali bagian-bagian komponen menjadi sistem yang lengkap, harapannya sebuah sistem dapat diperbaiki[1].

\section{B. Analisis Sistem}

Menurut Yakub, Analisa Sistem dapat diartikan sebagai suatu proses untuk memahami sistem yang ada, dengan menganalisa jabatan dan uraian tugas (business Users), proses bisnis (business process), ketentuan atau aturan (business rule), masalah dan mencari solusinya (business problem and business soulution), dan rencana-rencana perusahaan (business plan)[2].

Menurut Mulyato, Analisa Sistem adalah teori sistem umum yang sebagai sebuah landasan konseptual yang mempunyai tujuan untuk memperbaiki berbagai fungsi didalam sistem yang sedang berjalan agar menjadi lebih efisien, mengubah sasaran sistem yang sedang berjalan, merancang atau mengganti output yang sedang digunakan, untuk mencapai tujuan yang sama dengan seperangkat input yang lain (biasa jadi lebih sederhana dan lebih interatif) atau melakukan beberapa perbaikan serupa[3]

Sehingga dapat disimpulkan bahwa Analisis Sistem adalah teknik pemecahan masalah yang mengurai dan mempelajari sistem dan proses kerja untuk mengidentifikasi penyebabnya, menentukan solusi dan mengidentifikasi kebutuhan informasi yang harus memenuhi dengan solusi sistem.

\section{Sistem Pakar}

Menurut Siswanto Sistem Pakar adalah program AI dengan basis pengetahuan (knowledge base) yang diperoleh dari pengalaman/pengetahuan pakar/ahli dalam memecahkan persoalan pada bidang tertentu dan didukung mesin inferensi/inference engine melakukan penalaran/pelacakan terhadap sesuatu/fakta-fakta yang diberikan User/pemakai, dicocokan/matching dengan fakta-fakta dan aturan/kaidah yang ada dibasis pengetahuan setelah dilakukan pencarian, sehingga dicapai kesimpulan[4].

\section{Pendekatan Metode Inferensi}

Merlina dan Hidayat [5], Pendekatan metode inferensi ada dua, yaitu :
1) Backward Chaining: Backward Chaining adalah pendekatan goal-driven yang dimulai dari harapan apa yang akan terjadi (hipotesis) dan kemudian mencari bukti yang mendukung (atau berlawanan) dengan harapan. Sering, hal ini memerlukan perumusan dan pengujian hipotesis sementara (subhipotesis). Berikut adalah gambar dari cara kerja mesin inferensi Backward Chaining.

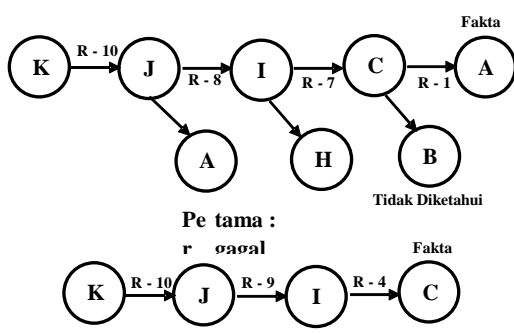

Gambar 1 Cara Kerja Mesin Inferensi Backward Chaining.

2) Forward Chaining: Forward Chaining adalah pendekatan data-driven yang dimulai dari informasi yang tersedia atau dari ide dasar, kemudian mencoba menarik kesimpulan. Berikut adalah gambar dari cara kerja mesin inferensi Forward Chaining.

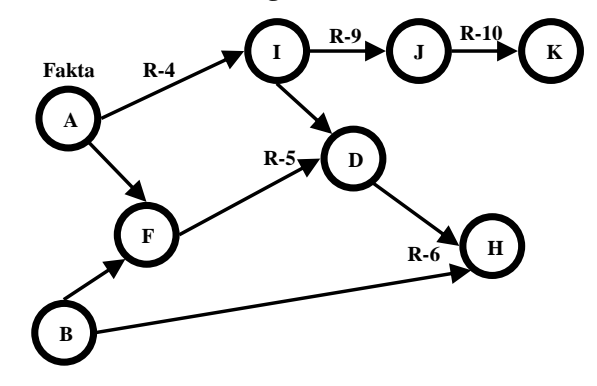

Gambar 2 Cara Kerja Mesin Inferensi Forward Chaining.

\section{METODOLOGI PENELITIAN}

A. Metode Pengumpulan Data

Adapun metode pengumpulan data yang penulis lakukan diantaranya, yaitu:

1) Observasi: Langkah pengamatan atau observasi ini dilakukan untuk mengamati dan mempelajari kondisi kegiatan dalam identifikasi kerusakan mobil daihatsu xenia 1.3 secara langsung. 
2) Wawancara: Pada metode ini penulis melakukan tanya jawab kepada pihak yang bersangkutan di saat melakukan penelitian yakni Bapak Mohamad Yunus sebagai Kepala Regu Mekanik dan Joko Santoso sebagai mekanik.

3) Studi Literatur: Studi ini dilakukan dengan mengumpulkan informasi atau data sebanyak-banyaknya dari kepustakaan dalam bentuk buku, jurnal, majalah, tesis, skripsi, artikel serta sumber-sumber lain yang berhubungan dengan penelitian.

\section{B. Metode Analisa dan Perancangan}

1) Metode Analisa: Metode analisis yang digunakan pada penelitian ini menggunakan pendekatan Object Oriented analysis (OOA) atau Analisis Berorientasi Objek dengan flowmap diagram. Proses analisis dilakukan terhadap hasil tahapan pengumpulan data dengan wawancara, observasi dan studi pustaka untuk mendapatkan spesifikasi kebutuhan sistem yang akan dikembangkan.

2) Metode Perancangan Sistem: Metode perancangan yang digunakan dalam penelitian ini menggunakan pendekatan metode Object Oriented Design (OOD) atau Perancangan Berorientasi Objek menggunakan Unifed Modelling Language (UML).

\section{Metode Pengembangan Sistem}

Metode yang akan digunakan dalam pengembangan aplikasi sistem pakar ini adalah metode waterfall yang merupakan model pengembangan khusus untuk pengembangan aplikasi. Secara garis besar, model ini membagi proses pengembangan aplikasi menjadi lima tahap, yaitu analisis, desain, pengodean, pelngujian, dan pemeliharaan.

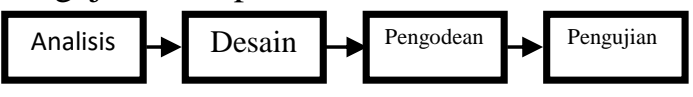

Gambar 3 Ilustrasi Model Waterfall

Berikut penjelasan kelima tahap metode pengembangan aplikasi:

1) Analisis: Pada tahap ini dilakukan analisis terhadap kebutuhan-kebutuhan sistem yang meliputi analisis data gejala dan kerusakan, proses akuisisi pengetahuan untuk pengambilan keputusan berdasarkan gejala kerusakan, serta pembuatan pohon keputusan.

2) Desain: Pada tahap ini akan dibuat perancangan aplikasi dengan menggunakan UML, Perancangan Database, dan desain antarmuka. Perancangan UML meliputi Usecase Diagram, Statechart Diagram, Activity Diagram, Sequence Diagram dan Class Diagram. Pada perancangan database dibuatnya tabel-tabel dan relasi antar tabel sedangakan pada desain antarmuka akan dibuat dengan menggunakan mockup.

3) Pengodean: Pada tahap ini dibangun sistem pakar yang menjadi objek penelitian. Sistem dibangun berdasarkan desain yang telah dibuat pada tahap sebelumnya. Dalam pembangunan sistem ini menggunakan bahasa pemrograman Java, XML, dan database SQLite. Bahasa pemrograman tersebut didukung oleh software Android Studio.

4) Pengujian: Pada tahap ini sistem yang telah dibangun dicoba apakah kebutuhan awal User atau User stories sudah dipenuhi dan apabila terpenuhi software siap dirilis.

5) Pemeliharaan: Tahap ini merupakan tahap terakhir dari pengembangan sistem. Tahap ini sistem yang telah dibuat akan dievaluasi. Hal ini memungkinkan terjadinya perubahan sesuai dengan kebutuhan pengguna. Pada penelitian ini, tahap ini belum diikut sertakan dan dibatasi hanya sampai pengujian.

\section{HASIL DAN PEMBAHASAN}

A. Analisa Sistem yang Berjalan

Analisis difokuskan pada sistem diagnosa yang terjadi pada kerusakan mobil. Bardasarkan metode analisis yang digunakan, maka berikut merupakan prosedur sistem yang sedang berjalan secara umum:

1) Customer datang ke bengkel membawa mobilnya yang sedang bermasalah. 
2) Service Advisor mencatat kondisi kendaraan Customer pada Bukti Serah Terima Kendaraan (BSTK) dan memberikan pertanyaan berupa masalah yang di alami mobil tersebut kepada pemilknya.

3) Service Advisor membuat Perintah Kerja Bengkel (PKB) sesuai dengan perbaikan yang akan di lakukan pada mobil tersebut

4) Service Advisor menyerahkan PKB ke mekanik.

5) Mekanik melakukan diagnosa kerusakan yang dialami mobil tersebut sesuai isi keluhan Customer yang tercatat di PKB.

6) Mekanik memberikan solusi perbaikan dari hasil diagnosa mobil tersebut.

Gambaran sistem diagnosa yang berjalan pada PT. Armada Auto Tara-Cabang Cikokol dapat dijelaskan seperti gambar dibawah ini :

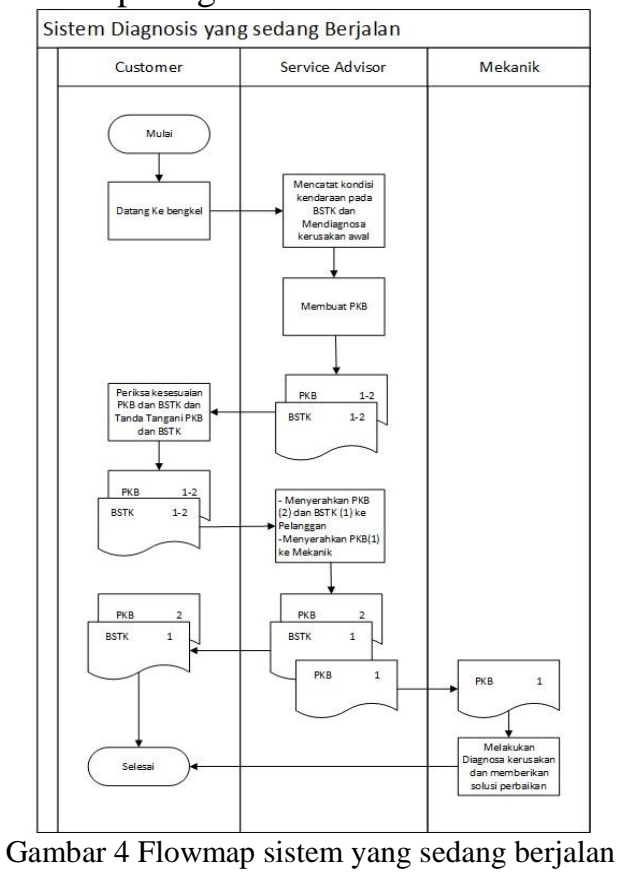

\section{B. Analisa Kebutuhan Sistem}

Kebutuhan fungsional merupakan jenis kebutuhan yang berisi proses apa saja yang nantinya dapat dilakukan oleh sistem, serta berisi informasi apa saja yang harus ada dan dihasilkan oleh sistem. Berikut kebutuhan fungsional sistem pakar diagnosa kerusakan pada mobil daihatsu xenia 1.3 :
1) Menampilkan menu pilihan atau menu utama

2) Menampilkan menu diagnosa, yaitu berisi pertanyaan gejala yang harus dipilih ole User

3) Menampilkan hasil diagnosa, yaitu berupa persentase kerusakan

4) Menampilkan menu informasi kerusakan, yaitu berisi data deskripsi dan solusi

5) Menampilkan menu bengkel terdekat, yaitu mengarahakan ke aplikasi google map dengan peencarian daihatsu terdekat dari lokasi User

6) Menampilkan menu tentang aplikasi

Untuk mengembangkan aplikasi Sistem Diagnosa Kerusakan pada Mobil Daihatsu Xenia 1.3 M/T dengan Metode Forward Chaining, peneliti membutuhkan beberapa perangkat lunak yang mendukung dalam pengerjaan aplikasi, yaitu:

Tabel 1 Perangkat Lunak

\begin{tabular}{|c|c|c|}
\hline Software & Versi & Fungsi \\
\hline $\begin{array}{l}\text { Android } \\
\text { Studio }\end{array}$ & 3.1 .3 & $\begin{array}{l}\text { Sebagai tempat untuk } \\
\text { mengembangkan kode } \\
\text { aplikasi dan pembuatan } \\
\text { layout. }\end{array}$ \\
\hline $\begin{array}{l}\text { Balsamiq } \\
\text { Mockups }\end{array}$ & 3.5 .15 & $\begin{array}{l}\text { Sebagai tempat untuk } \\
\text { membuat User Interface } \\
\text { program android }\end{array}$ \\
\hline $\begin{array}{l}\text { Nox } \\
\text { Player }\end{array}$ & 6.2 .1 .1 & $\begin{array}{l}\text { Sebagai emulator untuk } \\
\text { menjalankan aplikasi } \\
\text { android atau sebagai } \\
\text { ADB (Android Debug } \\
\text { Bridge) }\end{array}$ \\
\hline $\begin{array}{l}\text { PdaNet } \\
\text { for } \\
\text { Android }\end{array}$ & 5.1.0.5 & $\begin{array}{l}\text { Untuk menghubungkan } \\
\text { jaringan telepon } \\
\text { (smartphone) dengan } \\
\text { PC atau Laptop dengan } \\
\text { menggunakan kabel } \\
\text { data. }\end{array}$ \\
\hline
\end{tabular}

Adapun perangkat keras yang dibutuhkan oleh peneliti untuk mengembangkan aplikasi, berikut tabel perangkat keras:

Tabel 2 Perangkat Keras

\begin{tabular}{lll}
\multicolumn{4}{c}{ Spesifikasi } & \\
\hline Item & Lenovo Ideapad & $320-$ \\
& 14AST & \\
CPU Cores & $5 \quad$ COMPUTE & CORES \\
& 2C+3G (2 CPUs), $3.0 \mathrm{GHz}$ \\
Processor & AMD A9-9420 RADEON \\
Type & R5 & \\
RAM & 4 GB \\
Memory & $1 \mathrm{~TB}$ \\
\hline
\end{tabular}




\section{Analisa Kebutuhan Data}

Perancangan pada analisa data ini terdiri dari analisa data kerusakan dan data gejala. Hal tersebut akan dijelaskan pada uraian dibawah ini:

1) Data Kerusakan:

Tabel 3 Data Kerusakan

\begin{tabular}{ll}
\hline KODE & KERUSAKAN \\
\hline K001 & Throttle body \\
K002 & Busi Rusak \\
K003 & Malfungsi Fuel Injector \\
K004 & Kualitas Oli Sudah tidak bagus \\
K005 & Pompa bahan bakar \\
K006 & Mesin Overheating \\
K007 & Seal-seal/ring piston rusak \\
K008 & Malfungsi Idle Speed Control Valve (ISC) \\
K009 & Malfungsi Booster Rem \\
K010 & Piston Rem Macet \\
K011 & Kampas rem tipis \\
K012 & Master rem rusak \\
\hline
\end{tabular}

2) Data Gejala:

\begin{tabular}{ll} 
& \multicolumn{1}{c}{ Tabel 4 Data Gejala } \\
\hline KODE & GEJALA \\
\hline G001 & Akselerasi Tersendat/Buruk \\
G003 & Idle buruk \\
G004 & Tarin Brebet \\
G005 & Gas terasa nahan \\
G006 & RPM tinggi \\
G007 & Tidak ada loncatan bunga api \\
G008 & BBM boros \\
G009 & Kekentalan oli berkurang \\
G010 & Oli berubah warna \\
G011 & Mesin susah hidup \\
G012 & Mesin mogok \\
G013 & AC terasa panas \\
G014 & Temperatur mesin tinggi \\
G015 & Oli bercampur dengan air \\
G016 & Oli mesin berkurang \\
G017 & Lampu indikator oli pada dashboard \\
& hidup terus \\
G018 & Knalpot banyak mengeluarkan asap putih \\
G019 & Tercium bau menyengat pada knalpot \\
G020 & Suara mesin kasar \\
G021 & RPM naik turun \\
G022 & Mesin Brebet \\
G023 & Rem kurang pakem \\
G024 & Pedal rem terasa keras \\
G025 & Pedal rem terasa dalam \\
G026 & Terdengar bunyi mendesis ketika pedal \\
& rem di injak \\
G027 & Kuantitas minyak rem pada resevoir \\
& menurun \\
G028 & Saat di hidupkan mesin, pedal rem ketika \\
& di injak tidak merendah \\
\hline &
\end{tabular}

\begin{tabular}{ll}
\hline G029 & $\begin{array}{l}\text { Saat di rem mobil terasa narik ke } \\
\text { kanan/ke kiri } \\
\text { Terdengar bunyi decit saat di rem }\end{array}$ \\
G030 & $\begin{array}{l}\text { Pedal rem saat di kocok-kocok terasa } \\
\text { ngelos }\end{array}$ \\
\hline
\end{tabular}

\section{Analisa Kebutuhan Proses}

Untuk menghasilkan sistem pakar diagnosa kerusakan pada mobil Daihatsu Xenia 1.3 M/T yang baik diperlukan pembuatan basis pengetahuan, basis aturan dan pohon keputusan yang lengkap dan baik agar proses inferensi berjalan dengan baik.

\section{1) Basis Pengetahuan:}

Tabel 5 Basis Pengetahuan

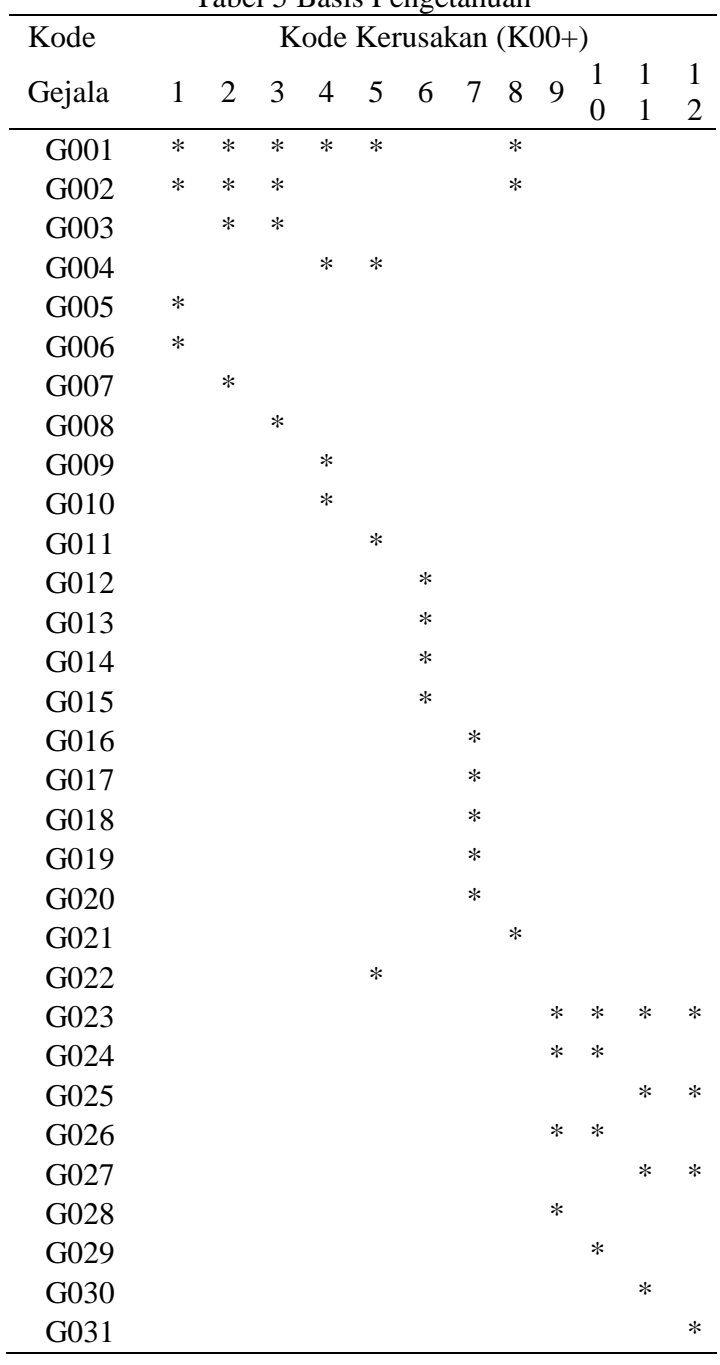

\section{2) Basis Aturan:}

Tabel 6 Basis Aturan 


\begin{tabular}{|c|c|}
\hline \multirow{3}{*}{$\mathrm{R} 1$} & IF G001 AND G002 AND G005 AND \\
\hline & G006 THEN K001 \\
\hline & IF G001 AND G002 AND G021 THEN \\
\hline \multirow[t]{2}{*}{$\mathrm{R} 2$} & K008 \\
\hline & IF G001 AND G002 AND G003 AND \\
\hline \multirow{2}{*}{$\mathrm{R} 3$} & G007 THEN K002 \\
\hline & IF G001 AND G002 AND G003 AND \\
\hline \multirow[t]{2}{*}{$\mathrm{R} 4$} & G008 THEN K003 \\
\hline & IF G001 AND G004 AND G009 AND \\
\hline \multirow[t]{2}{*}{ R5 } & G010 THEN K004 \\
\hline & IF G001 AND G004 AND G022 AND \\
\hline \multirow[t]{2}{*}{ R6 } & G011 THEN K005 \\
\hline & IF G013 AND G014 AND G012 AND \\
\hline \multirow[t]{2}{*}{ R7 } & G015 THEN K006 \\
\hline & IF G016 AND G017 AND G018 AND \\
\hline \multirow[t]{2}{*}{$\mathrm{R} 8$} & G019 AND G020 THEN K007 \\
\hline & IF G023 AND G024 AND G026 AND \\
\hline \multirow[t]{2}{*}{ R9 } & G028 THEN K009 \\
\hline & IF G023 AND G024 AND G026 AND \\
\hline \multirow[t]{2}{*}{$\mathrm{R} 10$} & G029 THEN K010 \\
\hline & IF G023 AND G025 AND G027 AND \\
\hline \multirow[t]{2}{*}{ R11 } & G030 THEN K011 \\
\hline & IF G023 AND G025 AND G027 AND \\
\hline $\mathrm{R} 12$ & G031 THEN K012 \\
\hline
\end{tabular}

3) Pohon Keputusan:

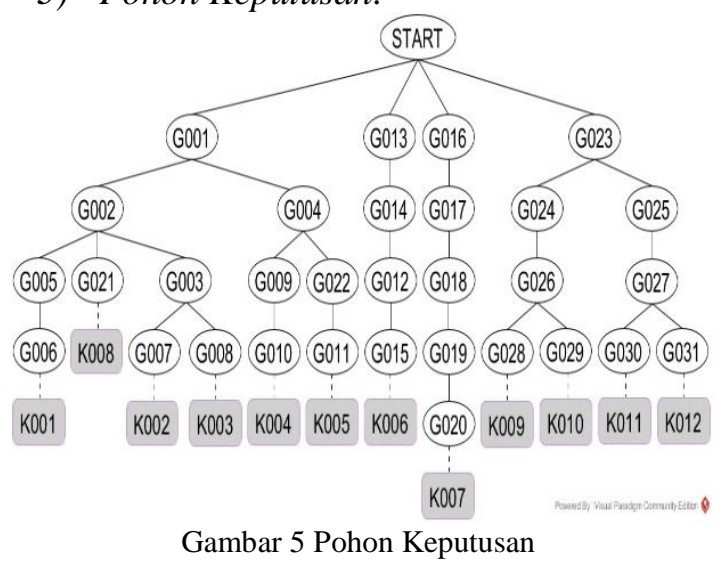

\section{E. Pemodelan Persoalan}

Dalam contoh berikut penulis hanya menampilkan pertanyaan yang jawabanya "Ya" saja. Pertanyaan pertama pada awal diagnosa adalah "Apakah mobil anda mengalami akselerasi tersendat/buruk?" karena ini merupakan pertanyaan yang paling utama. Selanjutnya akan tampil pertanyaan-pertanyaan seperti diawah ini:

1) Pada pertanyaan berikutnya pengguna $X$ menjawab "Ya", maka pertanyaan selanjutnya adalah "Apakah mobil anda mengalami idle buruk?".

2) Pada pertanyaan berikutnya pengguna $X$ menjawab "Ya", maka pertanyaan selanjutnya adalah "Apakah mobil anda mengalami gas terasa nahan?".

3) Pada pertanyaan berikutnya pengguna $X$ menjawab "Ya", maka pertanyaan selanjutnya adalah "Apakah mobil anda mengalami RPM tinggi?".

Dari pertanyaan tersebut maka didapat nilai total jawaban "YA" $=4$ dari total jumlah gejala dalam satu rule yaitu 4 pertanyaan. Kemudian sistem akan mencari probabillitas gejala kerusakan dengan menggunakan probabilitas klasik seperti persamaan dibawah ini.

$$
\begin{aligned}
\mathrm{P}(\mathrm{K}) & =\frac{T J}{T G} \times 100 \% \\
& =\frac{4}{4} \times 100 \%=100 \%
\end{aligned}
$$

Keterangan :

$\mathrm{P}(\mathrm{K})=$ Peluang Kerusakan

TJ = Total jumlah jawaban "YA"

$\mathrm{TG}=$ Total jumlah gejala dalam satu rule

Dari Perhitungan atas masing masing gejala diatas maka diperoleh jenis kerusakan (K001) yang dinyatakan untuk jenis kerusakan Throttle Body dengan nilai kepastian $=100 \%$

\section{F. Perancangan Sistem Usulan}

1) Usecase Diagram:

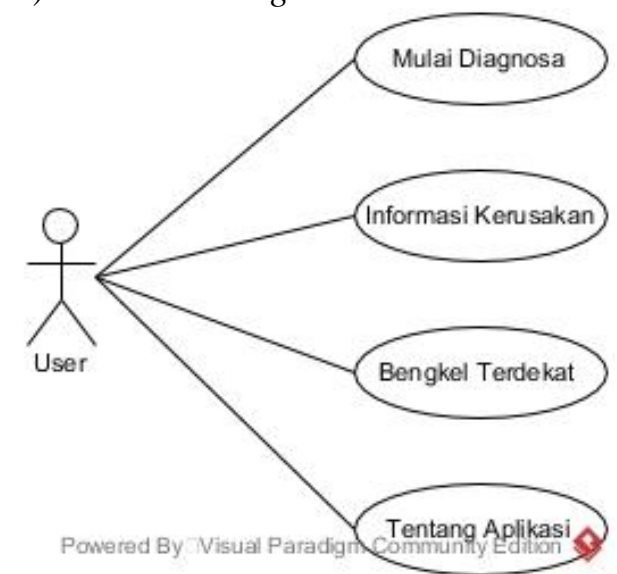

Gambar 6 Usecase Diagram Sistem Diagnosa Kerusakan pada Mobil Daihatsu Xenia 1.3 M/T

2) Statechart Diagram Mulai Diagnosa: 


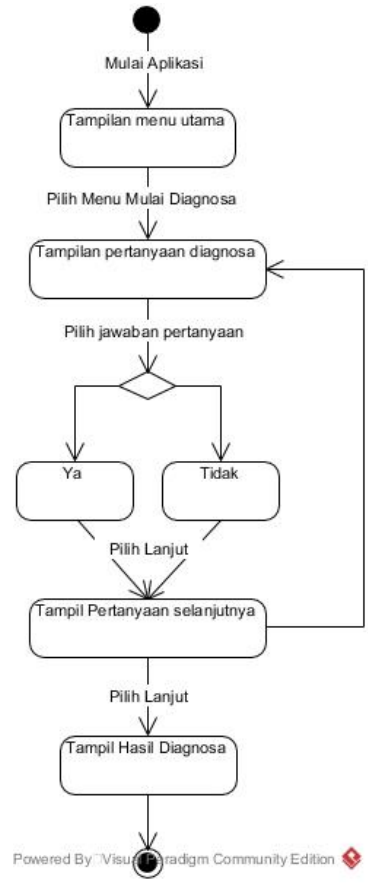

Gambar 7 Statechart Diagram Mulai Diagnosa

3) Activity Diagram Mulai Diagnosa:

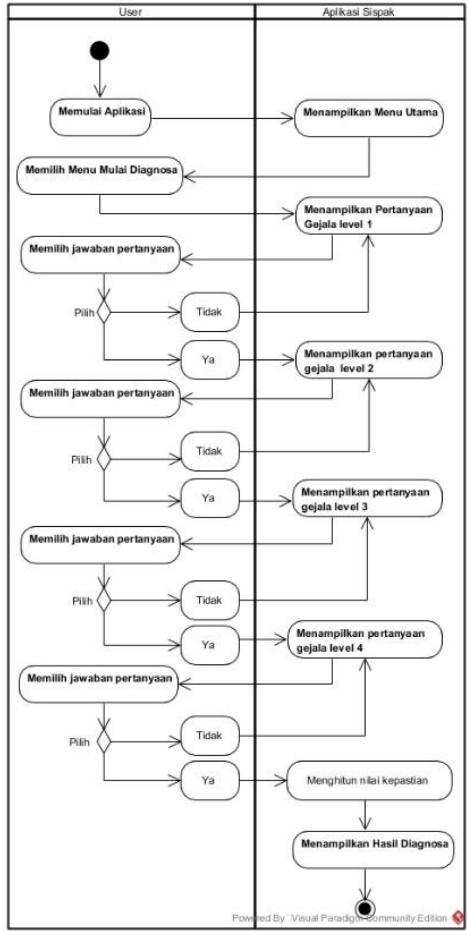

Gambar 8 Activity Digram Mulai Diagnosa

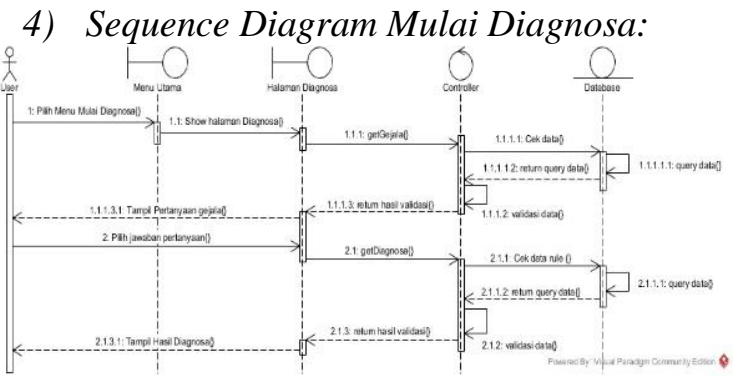

Gambar 9 Sequence Diagram Mulai Diagnosa

5) Class Diagram:

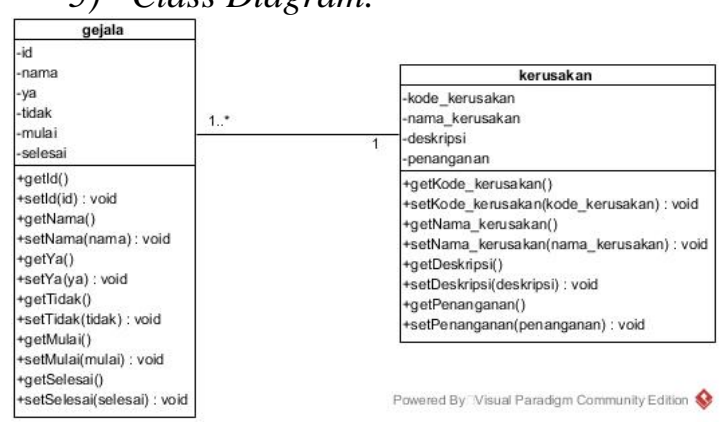

Gambar 10 Class Diagram Sistem Diagnosa Kerusakan pada Mobil Daihatsu Xenia 1.3 M/T

\section{G. Rancangan Database}

Pembuatan basis data dilakukan dengan menggunakan basis data SQLite yang diprogram langsung dari kelas basis data. Dalam tahap ini terdapat dua buah query untuk membentuk dua buah tabel, yaitu:

\section{1) Nama Tabel : Gejala} Media : :Harddisk

Isi : Gejala-gejala

Organisasi : Index Sequential

Akses File : Random

Primary Key : Id

Panjang Record: 280 karakter

Software : SQLite

Struktur Tabel: Lihat Tabel 7 
Tabel 7 Tabel Gejala

\begin{tabular}{lllll}
\hline No & Nama Field & Tipe Data & Panjang & Ket \\
\hline 1 & Id & TEXT & 5 & Id (PK) \\
2 & Nama & TEXT & 255 & Gejala \\
3 & Ya & VARCHAR & 5 & \\
4 & Tidak & VARCHAR & 5 & \\
5 & Mulai & VARCHAR & 5 & \\
6 & Selesai & VARCHAR & 5 & \\
\hline
\end{tabular}

2) Nama Tabel : Kerusakan

Media : Harddisk

Isi : Kerusakan

Organisasi : Index Sequential

Akses File : Random

Primary Key : kode_kerusakan

Panjang Record: 770 karakter

Software : SQLite

Struktur Tabel: Lihat Tabel 8

Tabel 8 Tabel Kerusakan

\begin{tabular}{|c|c|c|c|c|}
\hline No & Nama Field & Tipe Data & Panjang & Keterangan \\
\hline 1 & $\begin{array}{l}\text { kode_kerus } \\
\text { akan }\end{array}$ & $T E X T$ & 5 & $\begin{array}{l}\text { Kode } \\
\text { kerusakan } \\
\text { (PK) }\end{array}$ \\
\hline 2 & $\begin{array}{l}\text { nama_kerus } \\
\text { akan }\end{array}$ & $T E X T$ & 255 & $\begin{array}{l}\text { Nama } \\
\text { Kerusakan }\end{array}$ \\
\hline 3 & Deskripsi & $T E X T$ & 255 & Deskripsi \\
\hline 4 & Penanganan & $T E X T$ & 255 & Penanganan \\
\hline
\end{tabular}

H. Implementasi Sistem Pakar

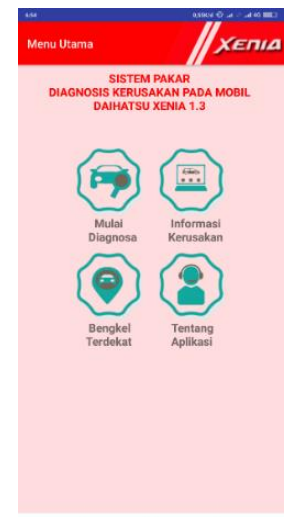

Gambar 11 Tampilan Layar Menu Utama

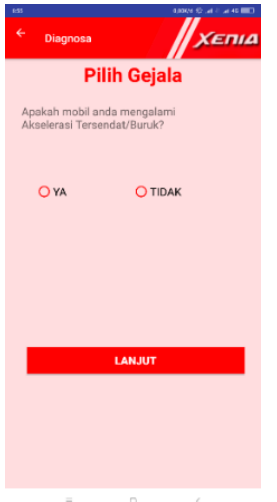

Gambar 12 Tampilan Layar diagnosa
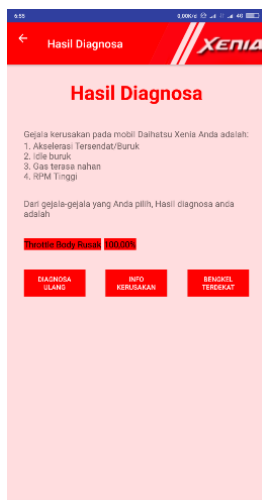

Gambar 13 Tampilan Layar Hasil Diagnosa

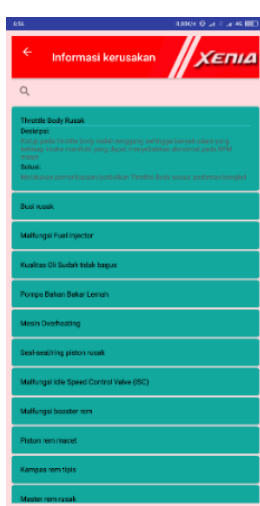

Gambar 14 Tampilan Layar Informasi Kerusakan 


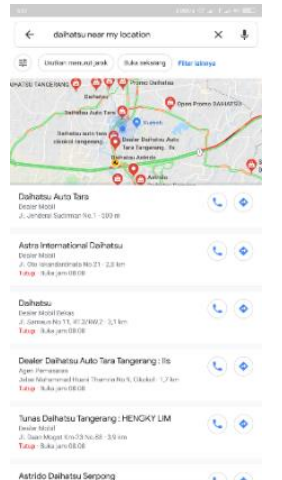

Gambar 15 Tampilan Layar Bengkel Terdekat

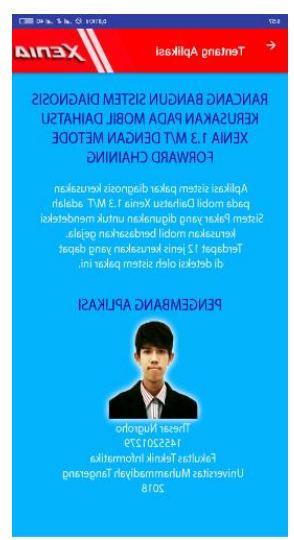

Gambar 16 Tampilan Layar Tentang Aplikasi

\section{Pengujian Sistem}

Tabel 9 Rencana Pengujian Fungsional Sistem Pakar

Tabel 10 Pengujian Fungsi Halaman Utama

\begin{tabular}{|c|c|c|c|}
\hline $\begin{array}{c}\text { Nama } \\
\text { Pengujian }\end{array}$ & $\begin{array}{c}\text { Bentuk } \\
\text { Pengujian }\end{array}$ & $\begin{array}{l}\text { Hasil yang } \\
\text { Diharapkan }\end{array}$ & $\begin{array}{c}\text { Hasil } \\
\text { Pengujian }\end{array}$ \\
\hline $\begin{array}{l}\text { Menguji } \\
\text { fungsi } \\
\text { menu } \\
\text { "Mulai } \\
\text { Diagnosa" }\end{array}$ & $\begin{array}{c}\text { Tekan } \\
\text { tombol } \\
\text { "Mulai } \\
\text { Diagnosa" }\end{array}$ & $\begin{array}{c}\text { Tampil } \\
\text { Halaman } \\
\text { Diagnosa }\end{array}$ & Berhasil \\
\hline $\begin{array}{c}\text { Menguji } \\
\text { fungsi } \\
\text { menu } \\
\text { "Informasi } \\
\text { Kerusakan" }\end{array}$ & $\begin{array}{c}\text { Tekan } \\
\text { tombol } \\
\text { "Informasi } \\
\text { Kerusakan" }\end{array}$ & $\begin{array}{c}\text { Tampil } \\
\text { Halaman } \\
\text { Informasi } \\
\text { Kerusakan }\end{array}$ & Berhasil \\
\hline $\begin{array}{l}\text { Menguji } \\
\text { fungsi } \\
\text { menu } \\
\text { "Bengkel } \\
\text { Terdekat" }\end{array}$ & $\begin{array}{c}\text { Tekan } \\
\text { tombol } \\
\text { "Bengkel } \\
\text { Terdekat" }\end{array}$ & $\begin{array}{l}\text { Tampil } \\
\text { halaman } \\
\text { google } \\
\text { map } \\
\text { pencarian } \\
\text { "Daihatsu } \\
\text { near my } \\
\text { location" }\end{array}$ & Berhasil \\
\hline $\begin{array}{l}\text { Menguji } \\
\text { fungsi }\end{array}$ & $\begin{array}{l}\text { Tekan } \\
\text { tombol }\end{array}$ & $\begin{array}{l}\text { Tampil } \\
\text { halaman }\end{array}$ & Berhasil \\
\hline
\end{tabular}

\begin{tabular}{|c|c|c|}
\hline $\begin{array}{c}\text { Item } \\
\text { Pengujian }\end{array}$ & Detail Pengujian & $\begin{array}{c}\text { Jenis } \\
\text { Pengujian }\end{array}$ \\
\hline & Penguiian funosi & \\
\hline & "Mulai Diagnosa" & Black Box \\
\hline & Penguijian fungsi & \\
\hline $\begin{array}{l}\text { Fungs1 } \\
\text { Halaman }\end{array}$ & "Informasi Kerusakan" & Black Box \\
\hline Hataman & Pengujian fungsi & \\
\hline Utama & "Bengkel Terdekat" & Black Box \\
\hline & Pengujian fungsi & \\
\hline & "Tentang Aplikasi" & Black Box \\
\hline & Pengujian masukan & Black Box \\
\hline & Pengujian masukan & 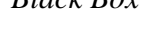 \\
\hline $\begin{array}{l}\text { Fungsi } \\
\text { Halaman }\end{array}$ & "Tidak" & Black Box \\
\hline Diagnosa & Pengujian masukan & \\
\hline & "Lanjut" & Black Box \\
\hline & Pengujian masukan & Black Box \\
\hline & Pengujian hasil & \\
\hline $\begin{array}{l}\text { Halaman } \\
\text { Hasil }\end{array}$ & \multirow{2}{*}{$\begin{array}{l}\text { diagnosa kerusakan } \\
\text { Penguiian fungsi }\end{array}$} & Black Box \\
\hline & & \\
\hline Diagnosa & "Back" & Black Box \\
\hline Halaman & \multirow{3}{*}{$\begin{array}{l}\text { Pengujian fungsi } \\
\text { informasi kerusakan } \\
\text { Pengujian fungsi } \\
\text { "Back" }\end{array}$} & \\
\hline Informasi & & Black Box \\
\hline Kerusakan & & Black Box \\
\hline menu & \multirow{3}{*}{$\begin{array}{l}\text { "Tentang } \\
\text { Aplikasi" }\end{array}$} & \\
\hline 'Tentang & & \\
\hline Aplikasi" & & \\
\hline
\end{tabular}

Tabel 11 Pengujian Fungsi Halaman Diagnosa

\begin{tabular}{|c|c|c|c|}
\hline $\begin{array}{c}\text { Nama } \\
\text { Pengujian }\end{array}$ & $\begin{array}{c}\text { Bentuk } \\
\text { Pengujian }\end{array}$ & $\begin{array}{l}\text { Hasil yang } \\
\text { Diharapkan }\end{array}$ & $\begin{array}{c}\text { Hasil } \\
\text { Pengujian }\end{array}$ \\
\hline $\begin{array}{l}\text { Menguji } \\
\text { fungsi } \\
\text { masukan } \\
\text { "Ya" }\end{array}$ & $\begin{array}{l}\text { Pilih } \\
\text { radio } \\
\text { button } \\
\text { "Ya" }\end{array}$ & $\begin{array}{l}\text { Memilih } \\
\text { gejala } \\
\text { kerusakan } \\
\text { yang } \\
\text { ditampilkan }\end{array}$ & Berhasil \\
\hline $\begin{array}{l}\text { Menguji } \\
\text { fungsi } \\
\text { masukan } \\
\text { "Tidak" }\end{array}$ & $\begin{array}{l}\text { Pilih } \\
\text { radio } \\
\text { button } \\
\text { "Tidak" }\end{array}$ & $\begin{array}{c}\text { Tidak } \\
\text { memilih } \\
\text { gejala } \\
\text { kerusakan } \\
\text { yang } \\
\text { ditampilkan }\end{array}$ & Berhasil \\
\hline $\begin{array}{l}\text { Menguji } \\
\text { fungsi } \\
\text { masukan } \\
\text { "Lanjut" }\end{array}$ & $\begin{array}{c}\text { Pilih } \\
\text { button } \\
\text { "Lanjut" }\end{array}$ & $\begin{array}{c}\text { Menampilkan } \\
\text { gejala } \\
\text { selanjutnya }\end{array}$ & Berhasil \\
\hline $\begin{array}{l}\text { Menguji } \\
\text { fungsi } \\
\text { menu } \\
\text { "back" }\end{array}$ & $\begin{array}{l}\text { Tekan } \\
\text { tombol } \\
\text { menu } \\
\text { "back" }\end{array}$ & $\begin{array}{c}\text { Tampil } \\
\text { halaman } \\
\text { utama sistem } \\
\text { pakar }\end{array}$ & Berhasil \\
\hline
\end{tabular}

Tabel 12 Pengujian Fungsi Halaman Informasi Kerusakan

\begin{tabular}{cccc}
\hline Nama & Bentuk & Hasil yang & Hasil \\
Pengujian & Pengujian & Diharapkan & Pengujian \\
\hline Menguji & Klik & Menampilkan & \\
fungsi & tombol & halaman & Berhasil \\
halaman & card & informasi & \\
& view" & kerusakan & \\
\hline
\end{tabular}




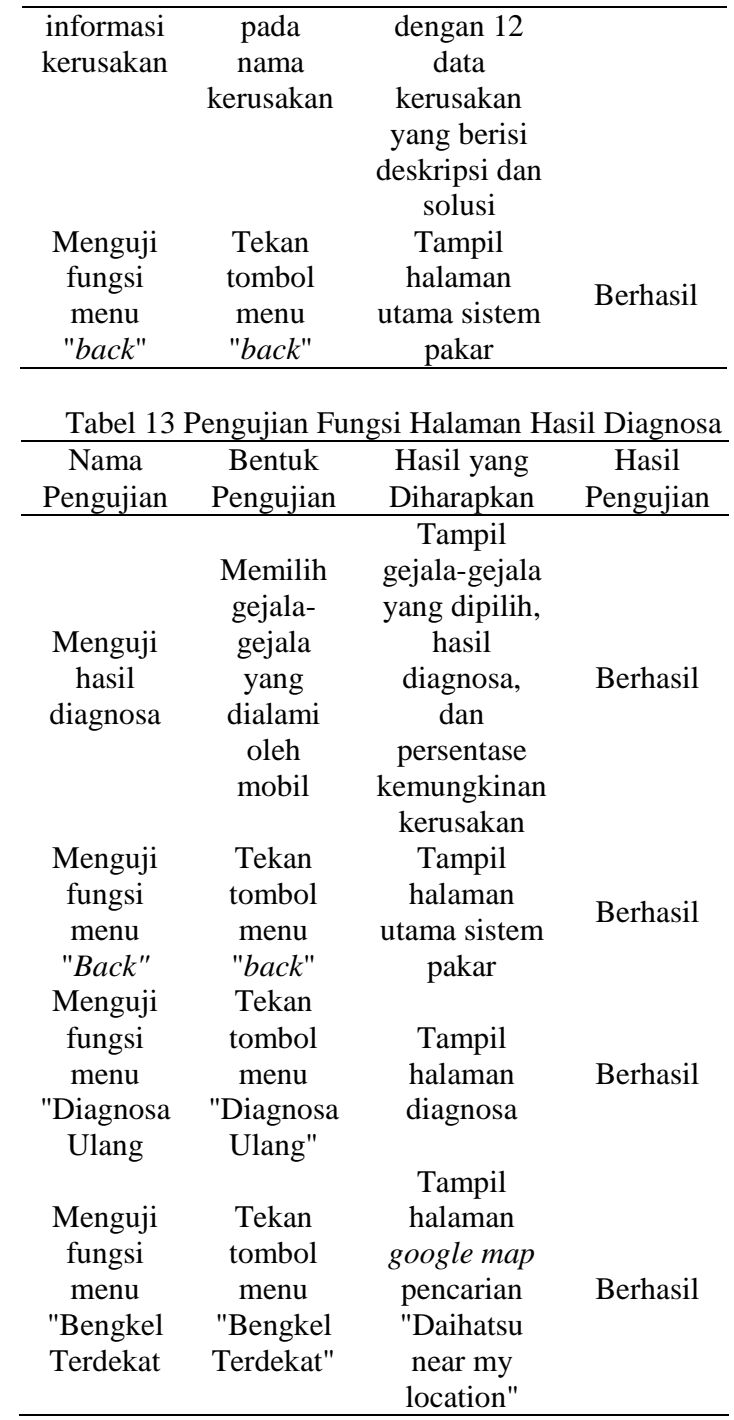

\section{KESIMPULAN}

Sistem diagnosa yang berjalan pada PT. Armada Auto tara meliputi proses penerimaan customer, pengecekan kondisi fisik kendaraan, konsultasi kerusakan kendaraan, proses pembuatan PKB, proses pengalokasian pekerjaan dan proses diagnosa kerusakan kendaraan.

Sistem pakar ini dapat mendiagnosa 12 kerusakan berdasarkan 31 gejala dan persentase gejala yang dikeluhkan pengguna mobil terhadap total gejala yang mungkin untuk suatu kerusakan telah dapat disajikan dengan probabilitas klasik.

Aplikasi sistem pakar berbasis mobile Android ini membantu User mendapatkan informasi tentang kerusakan yang dialami pada mobilnya tanpa harus datang ke bengkel atau ke ahli/pakar.

\section{REFERENSI}

[1] Muslihudin, Muhamad Oktafianto, 2016, Analisis dan Perancangan Sistem Informasi Menggunakan Model Terstruktur dan UML. Yogyakarta: Andi.

[2] Yakub, 2012, Pengantar Sistem Informasi Edisi Pertama. Yogyakarta: Graha Ilmu..

[3] Mulyanto, Agus, 2009, Sistem Informasi Konsep dan Aplikasi. Yogyakarta: Pustaka Pelajar.

[4] Siswanto, 2010, Kecerdasan Tiruan. Yogyakarta: Graha ilmu.

[5] Merlina, Nita, M.Kom \& Hidayat, Rahmat, S.Kom., 2012, Perancangan Sistem Pakar. Yogyakarta: Ghalia Indonesia.

[6] Gozzal, Reynaldo Mohammad, and Indarti, Dina, "Aplikasi Sistem Pakar Diagnosa Penyakit Pencernaan Balita dengan Metode Forward Chaining Berbasis Android," Jurnal Ilmiah Informatika dan Komputer., Vol. 22 No. 3, Desember. 2017.

[7] Perdana, Fery. Susilo, Andi and Sitorus, Sampe Hotlan, "Perancangan dan Implementasi Sistem Pakar Diagnosa Kerusakan Kendaraan Toyota Berbasis Android," Seminar Nasional Sains dan Teknologi 2015., November. 2015.

[8] Kurniawan, Setiadi, and Merlina, Nita, "Sistem Pakar Berbasis Web dengan Menggunakan Metode Forward Chaining untuk Mendiagnosa Kerusakan Mobil Daihatsu Ayla,"Jurnal Pilar Nusa Mandiri., Vol.11, No.2, September 2015. 